\title{
The Effect of Violation, Personal Costs, and Professional Commitment on Whistleblowing Intention
}

\author{
Khairani Amalia ${ }^{1}$, Mezia Wahyuni Heldi ${ }^{2}$, Muhammad Irlan ${ }^{3}$, Deni Darmawati ${ }^{4}$ \\ \{khairaniamalia1@gmail.com ${ }^{1}$, meziawahyuni88@gmail.com², irlandmuh@gmail.com ${ }^{3}$ \} \\ Universitas Trisakti, Jakarta, Indonesia ${ }^{1,2,3}$
}

\begin{abstract}
The purpose of this research is to determine the factors that influence whistleblowing intentions, namely seriousness level of violation, personal costs, and professional commitment. This research uses primary data, by distributing questionnaires to employees who work in the Local Government Work Unit (SKPD) of the Provincial Government of DKI Jakarta and West Sumatra with a total of 117 respondents. By using multiple regression analysis, this study found that seriousness level of violation, personal costs, and professional commitment have a positive effect on whistleblowing intentions. personal cost has a positive effect on the intensity of violations due to the existence of protection to whistleblowers. This research is expected to provide input for regulators to increase the effectiveness of the implementation of the whistleblowing system in government agencies by increasing the effectiveness of protection for whistleblowers and the professional commitment of employees.
\end{abstract}

Keywords: Seriousness Level of Violation; Personal Cost; Professional Commitment; Whistleblowing Intention

\section{Introduction}

Whistleblowing is a disclosure made by employees or former employees of an organization for an illegal, immoral, or without legal legitimacy practice under the control of their leadership to individuals or organizations that can have the effect of remedial action [1]. Meanwhile, a whistleblower is a person (employee/former employee in the organization) who performs an act of disclosing/notifying the public or top management about an alleged illegal/unethical act [2].

The implementation of whistleblowing in Indonesia is still faced with the bad fate of the perpetrators of disclosing fraud (whistleblowers) such as being ostracized in the organization until they become prisoners for revealing the fraudulent act. An example of a whistleblower case that ended tragically was the corruption case committed by Gayus Tambunan, in this case Susno Duadji was judged as a whistleblower because he had uncovered a major scandal involving two major agencies, namely the Police and the Directorate General of Taxes, the Indonesian Ministry of Finance. Susno Duadji, who revealed the alleged corruption, was finally fired from the police and sentenced to 3.5 years.

The examples of cases described above provide an indication that the role of whistleblowing actors is quite important in disclosing or reporting a case of fraud in an 
organization. This role is needed to detect early fraud or violations that occur in an organization. Although the whistleblowers are very at risk of retaliation and easy status changes to become a suspect with accusations of defamation. Therefore, the discussion of the factors that influence employees or members of the organization in carrying out whistleblowing intentions is still an interesting discussion. Even though there are laws that protect whistleblowers of violations or fraud, there are still other factors that make whistleblowers reconsider their intention to report [3].

There are several factors that make someone want to do whistleblowing. The factor that is considered to affect a person's intention to do whistleblowing is seriousness level of violation. Employees in a company who are aware of fraud will be more likely to do whistleblowing if the fraud is serious [4]. It can be concluded that the higher seriousness level of violation, the higher the intention of a person to report the fraud, because fraud that is considered serious will have a large impact on the organization and society [5]. Based on the results of research conducted by [6] that seriousness level of violations proved to have a positive effect on whistleblowing intentions.

The second factor that is considered to be able to influence a person's intention to carry out whistleblowing intentions is personal cost. Personal cost is an employee's perception of the risk of retaliation and sanctions from members of the organization, which can reduce the employee's intention to report wrongdoing [7]. Members of the organization in question may come from management, superiors, or colleagues. The personal costs felt by a whistleblower can be in the form of the risk and inconvenience of reporting and retaliation [8]. A person's perception of personal cost greatly influences that person's intention to take whistleblowing actions. According to [9], the greater a person's perception of personal cost, the less interest that person will be to take whistle-blowing actions. However, if the person feels that the impact they will receive is small, it will increase the person's tendency to take whistleblowing actions.

The third factor that is considered to be able to influence a person's intention to carry out whistleblowing intentions is professional commitment. Professional Commitment is the level of individual loyalty to his profession as perceived by the individual [10]. Whistleblowing can be described as a process that involves personal factors. The higher the professional commitment, the higher it will be to consider Whistleblowing to be an important thing. The researcher uses a combination of several independent variables that have been studied previously and is a renewal of the relationship between the new independent variable and the dependent variable. Professional commitment is believed to be able to influence employee intentions to carry out whistleblowing. Professional commitment is one of the important variables for an employee to do what is best for the organization. Research by Taylor and [9] provides empirical evidence that moral intensity is associated with reporting unethical acts (whistleblowing) with two reporting measures, namely likelihood of reporting and perseverance in reporting.

Based on the background that has been described, the authors will conduct research on employees in regional work units in DKI Jakarta, West Sumatra and on several auditors with the title "The Effect of Seriousness Level Of Violation, Personal Cost, and Professional Commitment on Whistleblowing Intention".

\subsection{Formulation of the Problems}

1. Does seriousness level of violation affect the whistleblowing intention?

2. Does personal costs affect whistleblowing intentions? 
3. Does professional commitment affect whistleblowing intentions?

\subsection{Research Objectives}

The research objectives to be achieved are to test about:

1. The effect of seriousness level of violation on the whistleblowing intention.

2. The effect of personal costs on whistleblowing intentions.

3. The effect of professional commitment on whistleblowing intentions.

\subsection{Benefit of the Research}

With the implementation of this research, of course, it is hoped that it can provide benefits for several related parties, including the following:

For Literature. For the development of the accounting literature, this study provides input on what factors influence whistleblowing intentions.

For the Practice Environment. (a) In the results of this research, it is hoped that the company's management will benefit from using the results of this study as consideration in making decisions and other policies so that it is expected to improve the whistleblowing system that can be applied in companies. (b) Employees will get information that can be learned so that later they can be more confident in carrying out whistleblowing acts c. For Accounting Students It is hoped that this research can be studied again and can also be used as an additional reference source to find out what preparatory matters can affect whistleblowing both in the government sector and private companies.

For the Government. Provide additional information and input on the importance of Seriousness Level of Violation that will occur, Seriousness Level of Violation, Personal Cost, and Professional Commitment whether it can influence the formation of Whistleblowing Intentions so that fraud can be detected early.

\section{Review of Related Literature and Hypothesis Development}

\subsection{Theory of Planned Behavior}

The Theory of Planned Behavior is the result of the development of The Theory of Reasoned Action (TRA) which explains that a person's intention to behave is shaped by two main factors, namely attitudes towards behavior and subjective norms. In the Theory of Planned Behavior (TPB) proposed by [11] perfecting The Theory of Reasoned Action (TRA) regarding the behavior carried out by individuals arises because of the intention of the individual for the behavior and the individual caused by several internal and external factors of the individual.

The Theory of Planned Behavior explains that an individual's intention to behave is determined by three factors:

a. Attitude to Behavior, this factor is the attitude of an individual in doing something will be in accordance with the attitude that is owned by a behavior.

b. Subjective Norms, when a person's actions or behavior will be influenced by the environment.

c. Perception of Behavioral Control, a factor that explains how a person can understand that the behavior he shows is the result of his own control. 
The Theory of Planned Behavior (TPB) is one of the theories that supports whistleblowing by trying to explain the relationship between attitudes and one's behavior. TPB emerged as an answer to the failure of attitude determinants in predicting actual actions/behaviors directly. TPB proves that interest (intention) is more accurate in predicting actual behavior and at the same time can be a proxy that connects attitudes and actual behavior.

\subsection{Whistleblowing}

According to [12] whistleblowing is the act of an employee or former employee to disclose what he or she believes to be illegal or unethical behavior to higher management/top management (internal whistleblowing) or to authorities/authorities outside the organization or to the public. (external whistleblowing). The party who does the whistleblowing is called the whistleblower. Whistleblower is someone who does see and witness an illegal/deviant act committed by a fellow member of his organization [13]. According to [14] a whistleblower has an important role as whistleblowers who can reveal various scandals, malpractices and corruption that occur in an organization. A person's intention to do whistleblowing can be measured from the intention to do whistleblowing, the desire to try whistleblowing, the plan to do whistleblowing, the effort to carry out internal whistleblowing and efforts to carry out external whistleblowing if internally it is not possible to use it [15].

\subsection{Seriousness Level of Violation}

Seriousness level of violation is a measure of the extent to which ethical issues are taken seriously by a function of the objective characteristics of the situation, the real judgment of others about the problem and the individual's tendency to exaggerate or minimize the seriousness of a problem. Each individual in the organization has different reactions to violations that occur in an organization. A violation can cause harm to the organization's internal and external parties. The greater the loss that will be created from an act of violation, the greater the desire of the organization to report alleged violations [5].

According to (Near, J.P. and Miceli, 1995) organizational members who know or observe wrongdoing or fraud, especially if the wrongdoing act is serious, then they will be more likely to want to take whistleblowing actions. This is because for him, the company will be affected in the form of large losses if the wrongdoing is large or serious. So it can be seen that the low or high level of seriousness of a fraud will determine whether someone will do whistleblowing or not. The seriousness of the violation can be seen from how big the impact caused by the fraud.

\subsection{Personal Cost}

[17] in Afuan define personal cost as an employee's view of the risk of retaliation/retaliation or sanctions from members of the organization, which can reduce employee interest in reporting wrongdoing. Members of the organization in question may come from management, superiors, or colleagues. The personal costs felt by a whistleblower can be in the form of the risk and inconvenience of reporting and retaliation (Lee and Xiao, 2018). Some retaliation can occur in intangible forms, such as unbalanced work appraisals, barriers to salary increases, termination of employment contracts, or being transferred to unwanted positions [9]. 
Personal costs may be based on subjective assessments [9], which means that perceptions of personal costs between employees may differ depending on their respective assessments. However, according to [16] the uniformity of the role of retaliation can still be traced, organizational members who lose their jobs or get disturbed after reporting wrongdoing may view reporting as an act that must be paid handsomely and punished [9]

\subsection{Professional Commitment}

[10] define professional commitment as the relative strength of individual identification with involvement in a profession and including belief in and acceptance of the goals and values of the profession, willingness to exert effort for the sake of the organization, and desire to maintain membership of a profession. According to Larkin translated by [18] states that:: "Professional commitment is the level of individual loyalty to the profession as perceived by the individual". According to Spector in [19] states that: "Professional commitment is a variable that reflects the degree of relationship considered owned by individuals towards certain professions in the organization". Professional commitment requires an employee to uphold the values and norms that apply in accordance with existing professional standards.

\subsection{Conceptual Framework}

The importance of this research is to determine the factors that influence whistleblowing intentions and the relationship of independent variables that are able to provide significant explanations for the independent variables. A framework of thought needs to be made to make it easier for readers to know the research model that is being built in a research. The following Figure 1 provide an overview of this research as a whole:

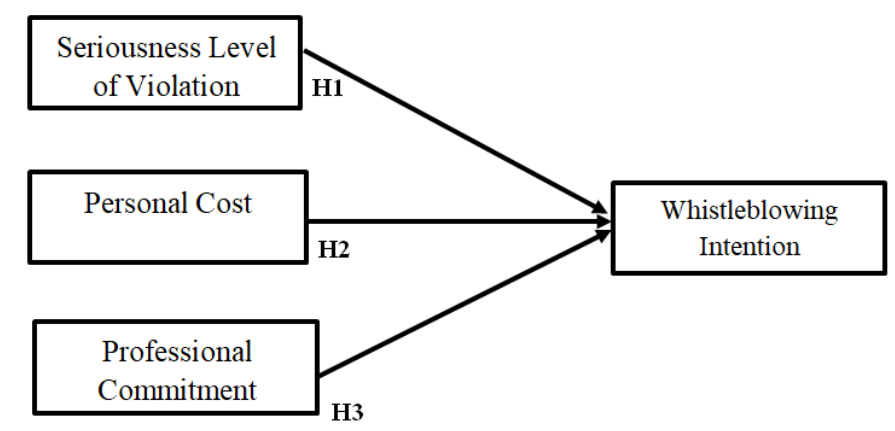

Fig. 1. The Conceptual Framework of Research

\subsection{Hypotheses Development}

\subsubsection{The Effect Of Seriousness Level of Violation on Whistleblowing Intention}

An organization will have a direct negative impact on more serious violations than for less serious violations. Organization members who observe an alleged violation will be more likely to do whistleblowing if the violation is serious [16]. According to [15] the level of fraud can affect the intention to do whistleblowing by using the Theory of Planned Behavior. According 
to [11] intention is assumed to capture the motivational factors that influence a behavior, which is indicated by how hard an individual plans to try to perform the behavior. Based on the Theory of Planned Behavior, intention is used as a factor to predict whistleblowing actions.

The seriousness of the error can be judged by how much loss can be experienced by the organization. Individuals tend to report serious errors rather than non-serious errors due to the individual's perception that the organization will experience greater losses if it is not reported immediately. In addition, individuals also feel they have a responsibility to protect their workplace from dangers and threats of loss [20]. The perception of each member of the organization on the seriousness of fraud may differ from one another. The shaper of the perception of the seriousness of fraud in addition to relating to the magnitude of the value of fraud, also cannot be separated from the type of fraud that occurs [7]. Research conducted by [13]; and [7] show that the level of seriousness of fraud affects a person's intention to do whistleblowing. So, based on this description, the following hypothesis is formulated:

$H 1$ : Seriousness level of violation has a positive influence on the Whistleblowing intention

\subsubsection{The Effect of Personal Cost on Whistleblowing Intention}

Personal Cost is an employee's perception of the risk of retaliation that will be received if he reports an act of violation/fraud that occurs within his organization [17]. One of the considerations for employees to report fraud in the procurement of goods/services as previously explained is the threat or retaliation from the perpetrators of fraud.

The threat of retaliation that may be received by an employee if he discloses fraud in the procurement of goods/services as described by [9], can be in the form of mutation to another section that is not in accordance with the competencies possessed and getting an unfair performance appraisal. In addition, postponing promotion can also be a form of personal cost that will be received by the employee. [21] say that the view of the threat of retaliation will put potential whistleblowers in a dilemma between doing what is right and suffering the consequences or just being silent and pretending not to know what happened. The dilemma of doubt determines this attitude which in the end can distort interest in reporting the fraud [7]. In the research of [22] and (Andika et al., 2021) it shows that personal cost has a positive effect on the intention to do whistleblowing. In this day and age, the whistleblowing system must be applied to large companies and state-owned enterprises. To help and protect the whistleblower, the company usually keeps the name of the fraud reporter secret. Moreover, there is legal protection against whistleblowers based on Law no. 31 of 2014 concerning the protection of witnesses and victims and how effective is the legal protection for whistleblowers in disclosing corruption cases in Indonesia, thereby making employees more confident, brave and confident to do whistleblowing.

Based on this explanation, the hypothesis is formulated:

H2 : Personal cost has a positive effect on Whistleblowing intentions

\subsubsection{The Effect of Professional Commitment on Whistleblowing Intentions}

Professional commitment is the belief in and acceptance of the goals of the profession and the willingness to exert great efforts on its behalf [24]. [24] emphasizes the importance of the study of professional commitment because a person's career is a major part of their life and professional commitment has important implications at the individual and organizational levels. Professional Commitment has a relationship with Whistleblowing Intentions, namely 
there are indications that employees who are more committed to their profession are more likely to carry out whistleblowing. Professional commitment will affect their perception of the importance of reporting suspicious actions. According to research by [25], there is a significant relationship between the level of effective professional commitment and professional goals or desires, where the higher the level of professional commitment, the higher the likelihood of someone doing whistleblowing. Thus, the higher a person's level of professional commitment, the higher the assumption that whistleblowing is important. Therefore, it is suspected that there is a relationship between the level of professional commitment and the importance of whistleblowing and their likelihood to do whistleblowing. This is consistent with the results of research conducted by [26],[25], and [27] which state that the level of professional commitment has a positive effect on intentions to whistleblowing.

Based on this, the hypothesis is formulated:

H3: Professional Commitment has a positive effect on Whistleblowing intentions

\section{Research Methods}

\subsection{Research Design}

This research is a type of hypothesis testing research, where research explains the causality of the relationship between variables, which is usually called a causal study [28]. The time horizon used in this study is a cross section, where data from each respondent is only collected once in order to answer research questions. The method chosen and will be used in this research is by using the survey method. The survey method is a method in which the data collection method is obtained from a set of objects of interest that have been determined previously [29]. In a survey, information is obtained by using a questionnaire whose data is collected from respondents or the population that will be the research sample.

Questionnaires are a way of obtaining data by providing a set of written questions to be answered by the respondents. Each question consists of various indicators that become a measuring tool for a variable. In this study there are two variables, namely the independent and dependent variables. Violation Seriousness Level, Personal Cost, and Professional Commitment as independent variables and Whistleblowing Intention as the dependent variable. The scale used for measurement is the Likert scale which is expressed with an interval of 1 to 5 . The Likert scale was chosen by us because the Likert scale is a scale used to measure the perception, attitude or opinion of a person or group regarding an event or social phenomenon, based on the definition operations that have been set by the researcher.

\subsection{Variables and Measurement}

This study uses 4 variables, which consist of the Seriousness of the Violation, Personal Cost, Professional Commitment, and Whistleblowing Intention.

\subsubsection{Seriousness Level of Violation}

This first variable is an independent variable that will affect the dependent variable. According to [16] organizational members who know or observe wrongdoing or fraud, especially if the wrongdoing act is serious, then they will be more likely to want to take whistleblowing actions. This variable will use the same indicators as [7]; and [15]. In this 
variable there are 5 question items that will be presented in the questionnaire. Each respondent will be asked to answer the questions (indicators) using an interval scale of 1-5 that has been developed by [29], with an answer range of 1 being strongly disagree, 2 is disagreeing, 3 is not agreeing, 4 is agreeing, 5 is strongly agree.

\subsubsection{Personal Cost}

Personal cost is one of the reasons why people do not want to report suspected violations because they believe that their reports will not be followed up, they will experience retaliation, or management will not protect them from the threat of retaliation, especially the types of violations that involve managers [30]. The threat of retaliation can take the form of rejection from co-workers, transfer to another department, rejection of salary increases, unfair performance appraisals (assessed as having low performance), even extreme forms of work termination [9]. In this variable there are 7 question items presented in the questionnaire. The measurement of the personal cost variable developed a questionnaire instrument that had been used by [31]. The instrument in the form of a questionnaire is measured using a 5-point Likert scale, and consists of 7 questions that must be filled out by the respondents.

\subsubsection{Professional Commitment}

[10] define professional commitment as the relative strength of individual identification with involvement in a profession and includes belief in and acceptance of the goals and values of the profession, willingness to exert effort for the sake of the organization, and desire to maintain membership of a profession. Professional commitment is defined as the liking formed by a person towards his profession [10] in [24]. A person who is committed to the profession believes in and accepts the goals of the profession and is willing to make various efforts to achieve the goals of the profession without being asked. In this variable there are 8 question items that will be presented in the questionnaire. This variable is measured based on professional characteristics according to Kalber L. and Forgaty and [32] using a 5-point Likert scale from strongly disagree to strongly agree.

\subsubsection{Whistleblowing Intention}

According to [12] whistleblowing is the act of an employee or former employee to disclose what he or she believes to be illegal or unethical behavior to higher management/top management (internal whistle-blowing) or to authorities/authorities outside the organization or to the public (external whistle-blowing). This variable is the dependent variable in this study. This variable measurement model follows the modified research questionnaire model of [11], [7], and [15]. The intention to take whistleblowing action consists of 5 statement items, namely: 1) the intention to carry out whistle-blowing actions, 2) the desire to try to carry out whistle-blowing actions, 3) plans to take whistleblowing actions, 4) hard efforts to carry out internal whistleblowing, and 5) endeavor to carry out external whistleblowing if internal whistleblowing is not possible. Similar to the previous variables, each respondent in this variable will answer each question using an interval scale of 1-5.

\subsection{Sample Collection Method}


[29] states that the sample is part of the number and characteristics possessed by the population. The population of this research is the employees in the regional work units in DKI Jakarta, West Sumatra, and to several external auditors.

\subsection{Data Collection Method}

Based on the data sources, this study uses primary data, namely data that are direct answers from the respondents concerned obtained from questionnaires, in order to obtain relevant, reliable, objective data, and can be used as a basis in the analysis process. Respondents who do not understand (ask) certain statements from the questionnaire, the researcher provides an explanation of the intent of these statements. The data collection technique used in the study was to provide questionnaires electronically to the respondents. Questionnaires will be distributed as many as 140 questionnaires with the aim of respondents being among employees in regional work units in DKI Jakarta, West Sumatra and to several auditors. Respondents will choose one of the alternative answers that have been provided to answer the questionnaire questions.

\subsection{Data Analysis Method}

The data analysis technique used in this study is multiple regression analysis to examine the effect of Seriousness Level of Violation (X1), Personal Cost (X2), Professional Commitment (X3) on Whistleblowing Intention (Y) The mathematical model in this study can be formulated as follows:

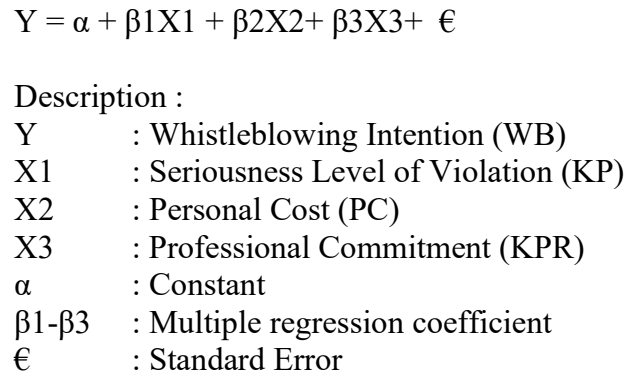

\section{Results and Discussion}

\subsection{Description of Data/Research Object}

Respondents who became the object of research were employees who worked in the Provincial Government of DKI Jakarta and West Sumatra. Samples were taken by distributing questionnaires via google docs link sent directly via whatsapp. The number of samples in this study were 117 respondents who were taken randomly. Table 1 shows a general description of the characteristics of the respondents: 
Table 1. Respondent Characteristic Profile

\begin{tabular}{ccccc}
\hline No & Respondent Profile & Criteria & Frequency & Percentage \\
1 & Gender & Male & 51 & $43,6 \%$ \\
& & Female & 66 & $56,4 \%$ \\
& & Total & 117 & $100 \%$ \\
2 & Age & $21-30$ Years & 34 & $29,1 \%$ \\
& & $31-40$ Years & 50 & $42,7 \%$ \\
& & -41 Years & 33 & $28,2 \%$ \\
& & Total & 117 & $100 \%$ \\
3 & Last Education & High School (SMA/SMK) & 10 & $8,5 \%$ \\
& & Associate Degree (D3) & 49 & $42 \%$ \\
& & Bachelor (S1) & 48 & $41 \%$ \\
& & Master (S2) & 10 & $8,5 \%$ \\
& & Doctor (S3) & 0 & $0 \%$ \\
4 & Working Period & Total & 117 & $100 \%$ \\
& & $1-5$ Years & 43 & $36,8 \%$ \\
& & 6-10 Years & 28 & $23,9 \%$ \\
& & $11-20$ Years & 46 & $39,3 \%$ \\
& & Total & 117 & $100 \%$ \\
\hline
\end{tabular}

\subsection{Descriptive Statistics Test Results}

In this study, researchers used descriptive statistical tests. Analysis using descriptive statistics is used to summarize the answers that have been given to respondents in the form of statements in the questionnaire. In this descriptive statistics section, the minimum, maximum, mean, mode and standard deviation values will be shown. The following are the results of descriptive statistical tests obtained based on the processed data. The descriptive statistics are shown in the Table 2:

Table 2. Descriptive Statistics Test Result

\begin{tabular}{lcccccc}
\hline \multicolumn{7}{c}{ Descriptive Statistics } \\
\hline & N & Minimum & Maximum & Sum & Mean & Std. Deviation \\
\hline AVGKP & 109 & 1.80 & 5.00 & 403.20 & 3.6991 & .65242 \\
AVGPC & 109 & 1.57 & 5.00 & 415.57 & 3.8126 & .73686 \\
AVGKPR & 109 & 2.88 & 5.00 & 436.25 & 4.0023 & .52346 \\
AVGWB & 109 & 2.20 & 5.00 & 436.40 & 4.0037 & .61943 \\
Valid N (listwise) & 109 & & & & & \\
\hline
\end{tabular}

From the table above, it can be seen and explained about the results of statistical calculations of the independent and dependent variables as follows:

a. In the variable Seriousness Level of Violation (KP) the minimum data is 1.80 and the maximum is 5.00 with an average (mean) of 3.6991 and a standard deviation of 0.65242 .

b. In the variable Personal Cost (PC) the minimum data is 1.57 and the maximum is 5.00 with an average (mean) of 3.8126 and a standard deviation of 0.73686 .

c. In the variable Professional Commitment (KPR) the minimum data is 2.88 and the maximum is 5.00 with an average (mean) of 4.0023 and a standard deviation of 0.52346 .

d. In the variable Whistleblowing Intention (WB) the minimum data is 2.20 and the maximum is 5.00 with an average (mean) of 4.0037 and a standard deviation of 0.61943 .

This indicates that the quality of the data from this study is quite good, because the mean value is greater than the standard deviation value which indicates that the standard error of each variable is small. 


\subsection{Data Quality Test Results}

Validity test is used to show the extent to which the measuring device is able to measure the object that has been determined so as to be able to obtain the required data properly. The validity test in this study was carried out with 25 statements consisting of 5 statements for the Violation Seriousness Level variable (X1), 7 questions for the Personal Cost variable (X2), 8 statements for the Professional Commitment variable (X3), and 5 statements for the Whistleblowing Intention variable. (Y). To find out whether each item in the instrument used is valid or not, it can be known by correlating the item score with the total score which is the sum of each item score. In calculating the validity test, this study uses the help of statistical tools in the SPSS for Windows Version 25 program. The results of the validity test for each variable described in Table 3, Table 4, Table 5, and Table 6:

Table 3. Validity Test Result of Whistleblowing Variable

\begin{tabular}{|c|c|c|c|c|c|c|c|}
\hline \multicolumn{8}{|c|}{ Correlations } \\
\hline & & $\begin{array}{c}\text { Whistlebl } \\
\text { owing }\end{array}$ & $\begin{array}{c}\text { Whistleblo } \\
\text { wing }\end{array}$ & $\begin{array}{c}\text { Whistleblo } \\
\text { wing }\end{array}$ & $\begin{array}{c}\text { Whistleb } \\
\text { owing }\end{array}$ & $\begin{array}{l}\text { Whistlebl } \\
\text { owing }\end{array}$ & TOTWB \\
\hline \multicolumn{2}{|c|}{ WhistlebloPearson } & 1 & $.815^{* *}$ & $.796^{* *}$ & $.567^{* *}$ & $.745^{* *}$ & $.884^{* *}$ \\
\hline \multirow[t]{3}{*}{ wing } & Correlation & & & & & & \\
\hline & Sig. (2-tailed) & & .000 & .000 & .000 & .000 & .000 \\
\hline & $\mathrm{N}$ & 109 & 109 & 109 & 109 & 109 & 109 \\
\hline \multicolumn{2}{|c|}{ WhistlebloPearson } & $.815^{* *}$ & 1 & $.892^{* *}$ & $.649^{* *}$ & $.720^{* *}$ & $.922^{* *}$ \\
\hline \multirow[t]{3}{*}{ wing } & Correlation & & & & & & \\
\hline & Sig. (2-tailed) & .000 & & .000 & .000 & .000 & .000 \\
\hline & $\mathrm{N}$ & 109 & 109 & 109 & 109 & 109 & 109 \\
\hline \multicolumn{2}{|c|}{ WhistlebloPearson } & $.796^{* *}$ & $.892^{* *}$ & 1 & $.642^{* *}$ & $.778^{* *}$ & $.928^{* *}$ \\
\hline \multirow[t]{3}{*}{ wing } & Correlation & & & & & & \\
\hline & Sig. (2-tailed) & .000 & .000 & & .000 & .000 & .000 \\
\hline & $\mathrm{N}$ & 109 & 109 & 109 & 109 & 109 & 109 \\
\hline \multicolumn{2}{|c|}{ WhistlebloPearson } & $.567^{* *}$ & $.649^{* *}$ & $.642^{* *}$ & 1 & $.718^{* *}$ & $.808^{* *}$ \\
\hline \multirow[t]{3}{*}{ wing } & Correlation & & & & & & \\
\hline & Sig. (2-tailed) & .000 & .000 & .000 & & .000 & .000 \\
\hline & $\mathrm{N}$ & 109 & 109 & 109 & 109 & 109 & 109 \\
\hline \multirow{4}{*}{$\begin{array}{l}\text { Whistlebl } \\
\text { wing }\end{array}$} & pearson & $.745^{* *}$ & $.720^{* *}$ & $.778^{* *}$ & $.718^{* *}$ & 1 & $.889^{* *}$ \\
\hline & Correlation & & & & & & \\
\hline & Sig. (2-tailed) & .000 & .000 & .000 & .000 & & .000 \\
\hline & $\mathrm{N}$ & 109 & 109 & 109 & 109 & 109 & 109 \\
\hline \multirow[t]{4}{*}{ TOTWB } & Pearson & $.884^{* *}$ & $.922^{* *}$ & $.928^{* *}$ & $.808^{* *}$ & $.889^{* *}$ & 1 \\
\hline & Correlation & & & & & & \\
\hline & Sig. (2-tailed) & .000 & .000 & .000 & .000 & .000 & \\
\hline & $\mathrm{N}$ & 109 & 109 & 109 & 109 & 109 & 109 \\
\hline
\end{tabular}

**. Correlation is significant at the 0.01 level (2-tailed).

Table 4. Validity Test Result of Seriousness Level of Violation Variable

\begin{tabular}{cccccc}
\hline \multicolumn{6}{c}{ Correlations } \\
\hline Seriousness & Seriousness & Seriousnes & Seriousnes & Seriousness & TOTKP \\
Level of & Level of & s Level of & s Level of & Level of & Violation \\
Violation & Violation & Violation & Violation & Violation \\
\hline
\end{tabular}




\begin{tabular}{|c|c|c|c|c|c|c|c|c|c|}
\hline \multicolumn{10}{|c|}{ Correlations } \\
\hline & & \multicolumn{2}{|c|}{$\begin{array}{c}\text { Seriousness } \\
\text { Level of } \\
\text { Violation }\end{array}$} & $\begin{array}{l}\text { Seriousness } \\
\text { Level of } \\
\text { Violation }\end{array}$ & $\begin{array}{c}\text { Seriousnes } \\
\text { s Level of } \\
\text { Violation }\end{array}$ & \multicolumn{2}{|c|}{$\begin{array}{l}\text { Seriousnes } \\
\text { s Level of } \\
\text { Violation }\end{array}$} & $\begin{array}{l}\text { Seriousness } \\
\text { Level of } \\
\text { Violation }\end{array}$ & TOTKP \\
\hline \multicolumn{2}{|c|}{ s Level of Correlation } & \multicolumn{2}{|c|}{1} & $.717^{* *}$ & $.557^{* *}$ & \multicolumn{2}{|c|}{$.710^{* *}$} & $.196^{*}$ & $.827^{* *}$ \\
\hline Violation & $\begin{array}{l}\text { Sig. } \\
\text { tailed) }\end{array}$ & & & .000 & .000 & \multicolumn{2}{|c|}{.000} & .041 & .000 \\
\hline & $\mathrm{N}$ & \multicolumn{2}{|c|}{109} & 109 & \multirow{2}{*}{$\begin{array}{c}109 \\
.832^{* *}\end{array}$} & \multicolumn{2}{|c|}{109} & 109 & 109 \\
\hline \multicolumn{2}{|c|}{ s Level of Correlation } & \multicolumn{2}{|c|}{$.717^{* *}$} & 1 & & \multicolumn{2}{|c|}{$.720^{* *}$} & .131 & $.876^{* *}$ \\
\hline Violation & $\begin{array}{l}\text { Sig. } \\
\text { tailed) }\end{array}$ & \multicolumn{2}{|c|}{.000} & & .000 & \multicolumn{2}{|c|}{.000} & .173 & .000 \\
\hline & $\mathrm{N}$ & & 109 & \multirow{2}{*}{$\begin{array}{c}109 \\
1\end{array}$} & \multicolumn{2}{|c|}{109} & 109 & 109 \\
\hline \multicolumn{2}{|c|}{$\begin{array}{l}\text { Seriousnes Pearson } \\
\text { s Level of Correlation }\end{array}$} & \multicolumn{2}{|c|}{$.557^{* *}$} & $.832^{* *}$ & & \multicolumn{2}{|c|}{$.685^{* *}$} & .148 & $.818^{* *}$ \\
\hline Violation & $\begin{array}{l}\text { Sig. } \\
\text { tailed) }\end{array}$ & \multicolumn{2}{|c|}{.000} & .000 & & .0 & & .124 & .000 \\
\hline & $\mathrm{N}$ & 1 & & 109 & 109 & 10 & & 109 & 109 \\
\hline $\begin{array}{l}\text { Seriousne } \\
\text { s Level o }\end{array}$ & $\begin{array}{l}\text { es Pearson } \\
\text { of Correlation }\end{array}$ & .71 & & $.720^{* *}$ & $.685^{* *}$ & 1 & & $.226^{*}$ & $.820^{* *}$ \\
\hline Violation & $\begin{array}{l}\text { Sig. } \\
\text { tailed) }\end{array}$ & .0 & & .000 & .000 & & & .018 & .000 \\
\hline & $\mathrm{N}$ & 1 & & 109 & 109 & 10 & & 109 & 109 \\
\hline $\begin{array}{l}\text { Seriousne } \\
\mathrm{s} \text { Level o }\end{array}$ & $\begin{array}{l}\text { es Pearson } \\
\text { of Correlation }\end{array}$ & .19 & & .131 & .148 & .22 & & 1 & .188 \\
\hline Violation & $\begin{array}{l}\text { Sig. } \\
\text { tailed) }\end{array}$ & - & & .173 & .124 & .0 & & & .050 \\
\hline & $\mathrm{N}$ & 1 & & 109 & 109 & 10 & & 117 & 109 \\
\hline TOTKP & $\begin{array}{l}\text { Pearson } \\
\text { Correlation }\end{array}$ & .82 & & $.876^{* *}$ & $.818^{* *}$ & .82 & & .188 & 1 \\
\hline & $\begin{array}{l}\text { Sig. } \\
\text { tailed })\end{array}$ & - & & .000 & .000 & .0 & & .050 & \\
\hline & $\mathrm{N}$ & 1 & & 109 & 109 & 10 & & 109 & 109 \\
\hline **. Correl & lation is signif & an & 0.01 & $\begin{array}{l}\text { vel }(2- \\
\text { eel }(2-t\end{array}$ & & & & & \\
\hline & & Tabl & it & ity Test Re & of Persona & al Cost V & able & & \\
\hline & & & & Correl & lations & & & & \\
\hline & & $\begin{array}{c}\text { Personal } \\
\text { Cost } \\
\end{array}$ & $\begin{array}{c}\text { Persona } \\
\text { Cost }\end{array}$ & \begin{tabular}{cc|} 
al & $\begin{array}{c}\text { Personal } \\
\text { Cost }\end{array}$ \\
\end{tabular} & $\begin{array}{c}\begin{array}{c}\text { Personal } \\
\text { Cost }\end{array} \\
\end{array}$ & $\begin{array}{l}\text { Personal } \\
\text { Cost }\end{array}$ & $\begin{array}{c}\text { Personal } \\
\text { Cost }\end{array}$ & $\begin{array}{cc}\text { al } & \begin{array}{c}\text { Personal } \\
\text { Cost }\end{array} \\
\end{array}$ & I TOTPC \\
\hline $\begin{array}{l}\text { Personal } \\
\text { Cost }\end{array}$ & $\begin{array}{l}\text { Pearson } \\
\text { Correlation }\end{array}$ & 1 & $.584^{* *}$ & $.675^{* *}$ & $.640^{* *}$ & $.604^{* * *}$ & -.063 & $.527^{* *}$ & $.759^{* *}$ \\
\hline & $\begin{array}{l}\text { Sig. } \\
\text { tailed })\end{array}$ & & .000 & .000 & .000 & .000 & .515 & .000 & .000 \\
\hline & $\mathrm{N}$ & 109 & 109 & 109 & 109 & 109 & 109 & 109 & 109 \\
\hline $\begin{array}{l}\text { Personal } \\
\text { Cost }\end{array}$ & $\begin{array}{l}\text { Pearson } \\
\text { Correlation }\end{array}$ & $.584^{* *}$ & 1 & $.656^{* *}$ & $.690^{* *}$ & $.664^{* *}$ & .010 & $.578^{* *}$ & $.838^{* *}$ \\
\hline & $\begin{array}{l}\text { Sig. } \\
\text { tailed) }\end{array}$ & .000 & & .000 & .000 & .000 & .921 & .000 & .000 \\
\hline & $\mathrm{N}$ & 109 & 109 & 109 & 109 & 109 & 109 & 109 & 109 \\
\hline Personal & Pearson & $.675^{* *}$ & $.656^{* *}$ & 1 & $.816^{* *}$ & $.606^{* *}$ & .062 & $.693^{* *}$ & $.882^{* *}$ \\
\hline Cost & $\begin{array}{l}\text { Correlation } \\
\text { Sig. } \\
\text { tailed })\end{array}$ & .000 & .000 & & .000 & .000 & .524 & .000 & .000 \\
\hline
\end{tabular}




\begin{tabular}{|c|c|c|c|c|c|c|c|c|c|}
\hline \multicolumn{10}{|c|}{ Correlations } \\
\hline & & $\begin{array}{c}\text { Personal } \\
\text { Cost }\end{array}$ & $\begin{array}{c}\text { Personal } \\
\text { Cost } \\
\end{array}$ & $\begin{array}{c}\text { Personal } \\
\text { Cost } \\
\end{array}$ & $\begin{array}{c}\text { Personal } \\
\text { Cost } \\
\end{array}$ & $\begin{array}{c}\text { Personal } \\
\text { Cost } \\
\end{array}$ & $\begin{array}{c}\text { Personal } \\
\text { Cost } \\
\end{array}$ & $\begin{array}{c}\text { Personal } \\
\text { Cost } \\
\end{array}$ & TOTPC \\
\hline & $\mathrm{N}$ & 109 & 109 & 109 & 109 & 109 & 109 & 109 & 109 \\
\hline \multirow{4}{*}{$\begin{array}{l}\text { Personal } \\
\text { Cost }\end{array}$} & Pearson & $.640^{* *}$ & $.690^{* *}$ & $.816^{* *}$ & 1 & $.700^{* * *}$ & -.010 & $.629^{* * *}$ & $.875^{* *}$ \\
\hline & Correlation & & & & & & & & \\
\hline & $\begin{array}{l}\text { Sig. } \\
\text { tailed) }\end{array}$ & .000 & .000 & .000 & & .000 & .915 & .000 & .000 \\
\hline & $\mathrm{N}$ & 109 & 109 & 109 & 109 & 109 & 109 & 109 & 109 \\
\hline \multirow{4}{*}{$\begin{array}{l}\text { Personal } \\
\text { Cost }\end{array}$} & Pearson & $.604^{* *}$ & $.664^{* *}$ & $.606^{* *}$ & $.700^{* * *}$ & 1 & -.131 & $.480^{* *}$ & $.783^{* *}$ \\
\hline & Correlation & & & & & & & & \\
\hline & $\begin{array}{l}\text { Sig. } \\
\text { tailed) }\end{array}$ & .000 & .000 & .000 & .000 & & .174 & .000 & .000 \\
\hline & $\mathrm{N}$ & 109 & 109 & 109 & 109 & 109 & 109 & 109 & 109 \\
\hline \multirow{4}{*}{$\begin{array}{l}\text { Personal } \\
\text { Cost }\end{array}$} & Pearson & -.063 & .010 & .062 & -.010 & -.131 & 1 & .030 & .003 \\
\hline & Correlation & & & & & & & & \\
\hline & $\begin{array}{l}\text { Sig. } \\
\text { tailed) }\end{array}$ & .043 & .161 & .124 & .018 & .024 & & .041 & .050 \\
\hline & $\mathrm{N}$ & 109 & 109 & 109 & 109 & 109 & 117 & 109 & 109 \\
\hline \multirow{4}{*}{$\begin{array}{l}\text { Personal } \\
\text { Cost }\end{array}$} & Pearson & $.527^{* *}$ & $.578^{* *}$ & $.693^{* *}$ & $.629^{* * *}$ & $.480^{* *}$ & .030 & 1 & $.770^{* * *}$ \\
\hline & Correlation & & & & & & & & \\
\hline & $\begin{array}{l}\text { Sig. } \\
\text { tailed) }\end{array}$ & .000 & .000 & .000 & .000 & .000 & .760 & & .000 \\
\hline & $\mathrm{N}$ & 109 & 109 & 109 & 109 & 109 & 109 & 109 & 109 \\
\hline \multirow[t]{3}{*}{ ТОТРС } & $\begin{array}{l}\text { Pearson } \\
\text { Correlation }\end{array}$ & $.759^{* *}$ & $.838^{* *}$ & $.882^{* *}$ & $.875^{* *}$ & $.783^{* * *}$ & .003 & $.770^{* *}$ & 1 \\
\hline & $\begin{array}{l}\text { Sig. } \\
\text { tailed })\end{array}$ & .000 & .000 & .000 & .000 & .000 & .977 & .000 & \\
\hline & $\mathrm{N}$ & 109 & 109 & 109 & 109 & 109 & 109 & 109 & 109 \\
\hline
\end{tabular}

**. Correlation is significant at the 0.01 level (2-tailed).

Table 6. Validity Test Result of Professional Commitment

\begin{tabular}{|c|c|c|c|c|c|c|c|c|c|c|}
\hline \multicolumn{11}{|c|}{ Correlations } \\
\hline & & $\begin{array}{l}\text { Professional } \\
\text { Comunitment }\end{array}$ & $\begin{array}{l}\text { Professional } \\
\text { Commnitment }\end{array}$ & $\begin{array}{l}\text { Professional } \\
\text { Commitment }\end{array}$ & $\begin{array}{l}\text { Professional } \\
\text { Commitment }\end{array}$ & $\begin{array}{l}\text { Professional } \\
\text { Commitment }\end{array}$ & $\begin{array}{l}\text { Professional } \\
\text { Commitment }\end{array}$ & $\begin{array}{l}\text { Professional } \\
\text { Commnitment }\end{array}$ & $\begin{array}{l}\text { Professional } \\
\text { Commitment }\end{array}$ & TOTKPR \\
\hline \multirow{3}{*}{$\begin{array}{l}\text { Profassional } \\
\text { Commitment }\end{array}$} & Pearson & 1 & $.478^{\prime \prime}$ & $-.191^{1}$ & $.779^{*}$ & $.372^{+2}$ & $.526^{17}$ & $.534^{\prime \prime}$ & $.553^{\prime \prime}$ & $.610^{27}$ \\
\hline & $\begin{array}{l}\text { Correlation } \\
\text { Sig. (2-tailed) }\end{array}$ & & .000 & .047 & .000 & .000 & .000 & .000 & .000 & .000 \\
\hline & & 109 & 109 & 109 & 109 & 109 & 109 & 109 & 109 & 109 \\
\hline \multirow{3}{*}{$\begin{array}{l}\text { Professional } \\
\text { Commitment }\end{array}$} & $\begin{array}{l}\text { Pearson } \\
\text { Carrelation }\end{array}$ & $.478^{\circ}$ & 1 & .055 & $.600^{\circ}$ & $.589^{\circ}$ & $.571^{\circ}$ & $.660^{\circ}$ & $.694^{\circ "}$ & $.743^{*}$ \\
\hline & Sig. (2-tailed) & .000 & & .569 & .000 & .000 & .000 & .000 & .000 & .000 \\
\hline & $\mathrm{N}$ & 109 & 109 & 109 & 109 & 109 & 109 & 109 & 109 & 109 \\
\hline \multirow{3}{*}{$\begin{array}{l}\text { Profassional } \\
\text { Commitment }\end{array}$} & Pearson & - $191^{*}$ & .055 & 1 & . .007 & $.333^{\circ \prime}$ & $.267^{\prime \prime}$ & $.248^{\prime \prime}$ & $.217^{\circ}$ & $.412^{\prime \prime}$ \\
\hline & $\begin{array}{l}\text { Correlation } \\
\text { Sig. (2-tailed) }\end{array}$ & .047 & .569 & & .939 & .000 & .005 & .009 & .024 & .000 \\
\hline & $\mathrm{N}$ & 109 & 109 & 109 & 109 & 109 & 109 & 109 & 109 & 109 \\
\hline \multirow[t]{3}{*}{$\begin{array}{l}\text { Professional } \\
\text { Commitment }\end{array}$} & $\begin{array}{l}\text { Pearson } \\
\text { Correlation }\end{array}$ & $.779^{\circ *}$ & $.600^{\circ}$ & .007 & 1 & $.460^{\circ}$ & $.674^{* \prime}$ & $.679^{\circ *}$ & $.685^{\prime \prime}$ & $.762^{\circ}$ \\
\hline & Sig. (2-tsilad) & .000 & .000 & .939 & & .000 & .000 & .000 & .000 & .000 \\
\hline & $\mathrm{N}$ & 109 & 109 & 109 & 109 & 109 & 109 & 109 & 109 & 109 \\
\hline \multirow[t]{3}{*}{$\begin{array}{l}\text { Professional } \\
\text { Commitment }\end{array}$} & $\begin{array}{l}\text { Pearson } \\
\text { Correlation }\end{array}$ & $.372^{\circ}$ & $.589^{\circ}$ & $.333^{\circ \prime}$ & $.460^{\circ}$ & 1 & $.724^{*}$ & $.723^{\circ}$ & $.702^{\prime \prime}$ & $.819^{\circ \prime}$ \\
\hline & Sig. (2-tailed) & .000 & .000 & .000 & .000 & & .000 & .000 & .000 & .000 \\
\hline & $\mathrm{N}$ & 109 & 109 & 109 & 109 & 109 & 109 & 109 & 109 & 109 \\
\hline \multirow[t]{3}{*}{$\begin{array}{l}\text { Professional } \\
\text { Commitment }\end{array}$} & $\begin{array}{l}\text { Pearson } \\
\text { Correlation }\end{array}$ & $.526^{\circ}$ & $.571^{\circ *}$ & $.267^{\circ}$ & $.674^{\circ}$ & $.724^{\circ}$ & 1 & $.880^{\circ}$ & $.833^{\circ *}$ & $.890^{\circ}$ \\
\hline & Sig. (2-tailad) & .000 & .000 & .005 & .000 & .000 & & .000 & .000 & .000 \\
\hline & $\mathrm{N}=12$ & 109 & 109 & 109 & 109 & 109 & 109 & 109 & 109 & 109 \\
\hline \multirow[t]{3}{*}{$\begin{array}{l}\text { Professional } \\
\text { Commitment }\end{array}$} & $\begin{array}{l}\text { Pearson } \\
\text { Correlation }\end{array}$ & $.534^{* *}$ & $.660^{\circ}$ & $.248^{\prime \prime}$ & $.679^{\circ *}$ & $.723^{\prime \prime}$ & $.880^{\circ}$ & 1 & $.937^{*}$ & $.919^{\circ \prime}$ \\
\hline & Sig. (2-tailed) & .000 & .000 & .009 & .000 & .000 & .000 & & .000 & .000 \\
\hline & $\mathrm{N}$ & 109 & 109 & 109 & 109 & 109 & 109 & 109 & 109 & 109 \\
\hline \multirow{3}{*}{$\begin{array}{l}\text { Professional } \\
\text { Commitment }\end{array}$} & Pearson & $.553^{\circ *}$ & $.694^{\circ "}$ & $.217^{\circ}$ & $.685^{\circ}$ & $.702^{*}$ & $.833^{\circ}$ & $.937^{\circ}$ & 1 & $.909^{\circ}$ \\
\hline & Sig. (2-tailed) & .000 & .000 & .024 & .000 & .000 & .000 & .000 & & .000 \\
\hline & $\mathrm{N}$ & 109 & 109 & 109 & 109 & 109 & 109 & 109 & 109 & 109 \\
\hline \multirow[t]{2}{*}{ TOTKPR } & Pearson & $.610^{\circ *}$ & $.743^{\circ+}$ & $.412^{*+}$ & $.762^{\prime \prime}$ & $.819^{\circ *}$ & $.890^{\circ "}$ & $.919^{\circ "}$ & $.909^{\prime \prime}$ & 1 \\
\hline & Sig. (2-tailad) & .000 & .000 & .000 & .000 & .000 & .000 & .000 & .000 & 10 \\
\hline
\end{tabular}


Based on the validity test in table 2-5 shows that the output value of sig ( 2 tailed) per variable $<0.05$ so that the validity test in this study can be declared valid and this research can be continued.

\subsection{Reliability Test Results}

Reliability testing is done to get answers that are consistent or stable from time to time. The reliability test was carried out using the SPSS 25 for windows program. To perform the reliability test, the Cronbach Alpha Reliability measurement method was used, an instrument can be said to be reliable if the alpha value is greater than 0.70 and vice versa. Table 7 shows the results of the reliability test using SPSS 25 for windows.

Table 7. Reliability Test Result

\begin{tabular}{lccc}
\hline \multicolumn{1}{c}{ Variable } & Question Items & Croanbach Alpha & Conclusion \\
\hline Seriousness Level of Violation (X1) & 5 & 0.796 & Reliable \\
Personal Cost (X2) & 7 & 0.844 & Reliable \\
Professional Commitment (X3) & 8 & 0.866 & Reliable \\
Whistleblowing Intention (Y) & 5 & 0.931 & Reliable \\
\hline
\end{tabular}

From the results of the reliability test above, it can be seen that each Cronbach Alpha value for the $\mathrm{X} 1$ variable is 0.796 , the $\mathrm{X} 2$ variable is 0.844 , the $\mathrm{X} 3$ variable is 0.866 and for the $\mathrm{Y}$ variable is 0.931 . The value of the four variables is greater than 0.70 which means that all variables $\mathrm{X}$ and $\mathrm{Y}$ are reliable.

\subsection{Normality Test Results}

The normality test used in this study is the Kolmogorov Smirnov test. This normality test aims to determine whether the data in the regression model is normally distributed or not. Table 8 shows the results of data normality test.

Table 8. Normality Test Result

\begin{tabular}{llc}
\hline \multicolumn{2}{c}{ One-Sample Kolmogorov-Smirnov Test } \\
& $\begin{array}{c}\text { Tnstandardized } \\
\text { Residual }\end{array}$ \\
\hline $\mathrm{N}$ & Mean & 109 \\
Normal Parameters ${ }^{\mathrm{a}, \mathrm{b}}$ & .0000000 \\
& Std. Deviation & .26376548 \\
Most Extreme Differences & Absolute & .095 \\
& Positive & .095 \\
& Negative & -.075 \\
Test Statistic & & .095 \\
Asymp. Sig. (2-tailed) & & $.016^{\mathrm{c}}$ \\
Exact Sig. (2-tailed) & & .259 \\
Point Probability & .000 \\
\hline a. Test distribution is Normal. & \\
b. Calculated from data. & \\
c. Lilliefors Significance Correction.
\end{tabular}

Based on the output of Kolmogorov Smirnov's normality results, in the table above, it can be seen that the significant value based on the Exact Sig method test is 0.259 or $25.9 \%$ Exact 
Sig value $>0.05$, it can be concluded that the residual data is normally distributed. In other words, the regression model of this study is normally distributed.

\subsection{Classic Assumption Test}

\subsubsection{Multicollinearity Test Results}

The multicollinearity test aims to test whether in the regression model that is formed there is a high or perfect correlation between the independent variables or not. In this study, the multicollinearity test used TOL (Tolerance) and VIF (Variance Inflation Factor) values. Detection of multicollinearity values can be done by looking at the VIF value from the results of the regression analysis. If the VIF value is $<10$, the data in the study is free from multicollinearity symptoms. Table 9 shows the results of the multicollinearity test:

\begin{tabular}{|c|c|c|c|}
\hline \multicolumn{4}{|c|}{ Coefficients $^{\mathbf{a}}$} \\
\hline & \multirow[t]{2}{*}{ Model } & \multicolumn{2}{|c|}{ Collinearity Statistics } \\
\hline & & Tolerance & VIF \\
\hline \multirow[t]{4}{*}{1} & (Constant) & & \\
\hline & AVGKP & 0.505 & 1.980 \\
\hline & AVGPC & 0.897 & 1.115 \\
\hline & AVGKPR & 0.486 & 2.059 \\
\hline
\end{tabular}

Based on the test results in the table above, it can be seen that all VIF values of all independent variables in this study have VIF values $<10$. This shows that the regression model is reliable and objective, so it can be concluded that the regression model is free from multicollinearity symptoms.

\subsubsection{Heteroscedasticity Test Results}

In this study, the heteroscedasticity test used the Glejser test. Table 10 shows the results of the heteroscedasticity test:

\begin{tabular}{llccccc}
\multicolumn{7}{c}{ Table 10. Heteroscedasticity Test Result } \\
\hline \multirow{2}{*}{ Model } & \multicolumn{2}{c}{ Coefficients $^{\mathbf{a}}$} & & \\
& & Unstandardized & Standardized & T & Sig. \\
& Coefficients & Coefficients & & \\
\cline { 2 - 5 } & B & Std. Error & Beta & & \\
\hline 1 & (Constant) & .530 & .149 & & 3.561 & .001 \\
& AVGKP & -.035 & .037 & -.126 & -.954 & .342 \\
& AVGPC & .007 & .024 & .029 & .294 & .770 \\
& AVGKPR & -.059 & .047 & -.170 & -1.265 & .209 \\
\hline
\end{tabular}

a. Dependent Variable: ABSRES

A data is said to contain heteroscedasticity if its significance value is less than 0.05 . From the results of the Glejser test the data of this study were obtained that all the significance values of all variables were above 0.05 . So from the results of the Glacier test it can be concluded that the residual data does not occur heteroscedasticity. 


\subsubsection{Autocorrelation Test Results}

The autocorrelation test used in this study was the Durbin-Watson test. The autocorrelation test is used to determine whether or not there is a correlation between the residuals in an observation and other observations in the regression model. The prerequisite that must be met is the absence of autocorrelation in the regression model. Table 10 shows the Autocorrelation Test Result and Fig. 2 shows the multiple regression model.

Table 10. Autocorrelation Test Result

\begin{tabular}{cccccc}
\hline Model & R & R Square & Model Summary & \\
\hline & & & & $\begin{array}{c}\text { Adjusted R Square } \\
\text { Estimate }\end{array}$ & \\
\hline 1 & $.905^{\mathrm{a}}$ & .819 & .813 & .26751 & 2.022 \\
\hline
\end{tabular}

a. Predictors: (Constant), AVGKPR, AVGPC, AVGKP

b. Dependent Variable: AVGWB

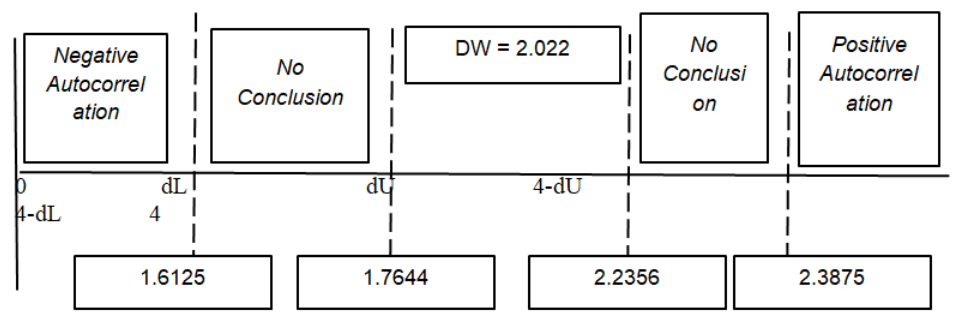

Fig. 2. Multiple Regression Model

Table 10 showsthat the multiple regression model has met the assumption of free autocorrelation. This can be seen from the calculated DW value of 2.022 which is in the area where there is no autocorrelation, which is in the range of DL $<\mathrm{DW}<4$-DU which is 1.6125 $<2.022<2.2356$, the value of 2.2356 is obtained from the result of subtracting 4 minus 1.7644. So it can be concluded that there is no autocorrelation in the data.

\subsection{Hypothesis Test}

\subsubsection{Coefficient of Determination Test Result}

Test the regression model or test the coefficient of determination between the variables of Seriousness of Violation, Personal Cost, and Professional Commitment as the independent variable on Whistleblowing Intention as the dependent variable. Table 11 shows the result of coefficient of determination result.

Table 11. Coefficient of Determination Test Result

\begin{tabular}{cccccc}
\hline Model & R & R Square & $\begin{array}{c}\text { Model Summary } \\
\text { Adjusted R } \\
\text { Square }\end{array}$ & $\begin{array}{c}\text { Std. Error of the } \\
\text { Estimate }\end{array}$ & Durbin-Watson \\
\hline 1 & $.905^{\mathrm{a}}$ & .819 & .813 & .26751 & 2.022 \\
\hline
\end{tabular}

a. Predictors: (Constant), AVGKPR, AVGPC, AVGKP

b. Dependent Variable: AVGWB 
The table above explains that Adjusted R Square (coefficient of determination) $=0.813$ means that the variation of the independent variable is able to explain the variation of the dependent variable is $81.3 \%$. While the rest $(100 \%-81.3 \%=18.7 \%)$ are variations of other independent variables that affect Whistleblowing Intentions that are not included in this study.

\subsubsection{F Test (Simultaneous Test)}

Simultaneous $\mathrm{F}$ test is a form of testing carried out to see the effect simultaneously or simultaneously between the independent variables on the dependent variable. Table 12 shows the results of the F Test or Simultaneous Test:

Table 12. F-test Result

\begin{tabular}{clccccc}
\hline \multicolumn{7}{c}{ ANOVA $^{\mathbf{a}}$} \\
\hline & \multicolumn{1}{c}{ Model } & Sum of Squares & df & Mean Square & F & Sig. \\
\hline 1 & Regression & 33.925 & 3 & 11.308 & 158.025 & $.000^{\mathrm{b}}$ \\
& Residual & 7.514 & 105 & .072 & & \\
& Total & 41.439 & 108 & & & \\
\hline
\end{tabular}

a. Dependent Variable: AVGWB

b. Predictors: (Constant), AVGKPR, AVGPC, AVGKP

Based on the table above, it is known that the significant value is 0.000 or less than the probability value ( $p$-value) of $0.000(0.000<0.05)$ this means that the independent variables have a significant effect simultaneously (simultaneously) on the dependent variable. In addition, the calculated $F$ value, which is 158,025 , is greater than the F-table value, which is 2.69 , so it can be concluded that together the independent variables have a significant effect on the dependent variable or KP, PC, KPR jointly affect WB.

\subsubsection{Partial t-Test (Individual Test)}

This test is done by looking at the significance value of the relationship of each variable. The level of significance $(\alpha)$ that is set is $5 \%$, which means that the tolerable error tolerance limit is $5 \%$. In other words, the level of confidence from this propositional test is $95 \%$. If the p-value $<0.05$, it can be said that the independent variable has a significant effect on the dependent variable. Table 13 shows the result of t-test.

Table 13. t-test Result

\begin{tabular}{|c|c|c|c|c|c|c|}
\hline \multicolumn{7}{|c|}{ Coefficients $^{\mathrm{a}}$} \\
\hline & \multirow[t]{2}{*}{ Model } & \multicolumn{2}{|c|}{ Unstandardized Coefficients } & \multirow{2}{*}{$\begin{array}{c}\begin{array}{c}\text { Standardized } \\
\text { Coefficients }\end{array} \\
\text { Beta }\end{array}$} & \multirow[t]{2}{*}{$\mathbf{T}$} & \multirow[t]{2}{*}{ Sig. } \\
\hline & & B & Std. Error & & & \\
\hline \multirow[t]{4}{*}{1} & (Constant) & -.486 & .224 & & -2.164 & .033 \\
\hline & AVGKP & .314 & .056 & .330 & 5.651 & .000 \\
\hline & AVGPC & .096 & .037 & .115 & 2.612 & .010 \\
\hline & AVGKPR & .740 & .071 & .625 & 10.488 & .000 \\
\hline
\end{tabular}

a. Dependent Variable: AVGWB

Hypotheses :

H0: there is no effect between $\mathrm{X}$ and $\mathrm{Y}$ 
$\mathrm{Ha}$ : there is an influence between $\mathrm{X}$ and $\mathrm{Y}$

Based on the significance value:

$\mathrm{H} 0$ is rejected and $\mathrm{Ha}$ is accepted if the significance is $<0.05$

$\mathrm{HO}$ is accepted and $\mathrm{Ha}$ is rejected if the significance is $>0.05$

Based on the results of the t-test above, it can be explained as follows:

1. In the table above, the Sig value of Seriousness Level of Violation variable $(\mathrm{X} 1)=0.000$ $<0.05$ so H0 is rejected, which means the independent variable Seriousness Level of Violation (X1) partially has a positive and significant effect on Whistleblowing Intention (Y).

2. In the table above, the Sig value of the Personal Cost variable (X2) $=0.010<0.05$ so H0 is rejected, which means that the independent variable Personal Cost (X2) partially has a positive and significant effect on the Whistleblowing Intention variable (Y).

3. In the table above, the Sig value of the Professional Commitment variable (X3) $=0.000<0.05$ so $\mathrm{H} 0$ is rejected, which means that the independent variable Professional Commitment (X3) partially has a positive and significant effect on the Whistleblowing Intention variable (Y).

\section{Conclusion}

Based on the results of the analysis that has been carried out in the previous chapter, it can be concluded as follows:

1. Based on the results of the partial test, it proves that Seriousness Level of Violation variable has a positive and significant effect on Whistleblowing Intentions. Hypothesis H1 can be accepted because the level of seriousness of violations has a positive effect on a person's intention to carry out whistleblowing intentions

2. The results of the partial test prove that the Personal Cost variable has a positive and significant effect on Whistleblowing Intentions. Hypothesis H2 is acceptable because the level of seriousness indicates a positive relationship with a person's intention to carry out whistleblowing intentions.

3. The results of the partial test prove that the Professional Commitment variable has a positive and significant effect on Whistleblowing Intentions. Hypothesis H3 can be accepted because professional commitment has a positive effect on a person's intention to carry out whistleblowing intentions.

\section{Limitations}

This research cannot be separated from limitations and weaknesses. On the other hand, the limitations and weaknesses found in this study are expected to be input for future research. The limitations found in this study, among others:

1. The research sample is still limited in several SKPDs in the provincial governments of DKI Jakarta and West Sumatra, and the distribution of the questionnaire was carried out with only 117 samples.

2. There is no right or wrong in filling out the questionnaire so that the measurement only relies on subjective measurements or is based on the respondent's perception only. Subjective measurement is prone to the emergence of bias or measurement error. 


\section{Recommendation}

Based on the research result, the authors provide suggestions are as follows:

1. For management

This research can be used as material for evaluating performance related to decision making in working in an SKPD. And anticipation for management to reduce a level of violations that occur among employees in the realm of work.

2. For future researcher

a. Consider the addition of other variables that can affect the whistleblowing intention of employees in disclosing fraud that occurs in their work environment.

b. Increase the number of samples in order to get varied answers and different points of view.

c. For further researchers, in order to consider distributing questionnaires at the managerial level and it would be even better if they could reach respondents who are at a higher level of work.

d. Make improvements and develop questionnaires and research instruments, to produce better variable measurements.

\section{References}

[1] J. K. N Brennan, "A Study of Whistle-blowing Among Trainee Auditors," Br. Account. Rev., vol. 39, pp. 61-87, 2007.

[2] G. Susmanchi, "Internal Audit And Whistle-Blowing. Management and Financial Markets," pp. 415-421, 2012.

[3] K. S. Damayanthi, "Pengaruh Norma Subyektif, Sikap Pada Perilaku, Presepsi Kontrol Perilaku Terhadap Niat Melakukan Pengungkapan Kecurangan (Whistleblowing)," Universitas Pendidikan Ganesha Singaraja, 2017.

[4] M. P. dan J. P. N. Miceli, "Characteristics of Organizational Climate and Perceived Wrongdoing Associated with Whistle-Blowing Decisions. Personnel Psychology," 1985, pp. 525-544.

[5] N. Elsya, "Profesional, Pengaruh Komitmen Keseriusan, Tingkat Dan, Pelanggaran Demografi, Faktor Intensi, Terhadap Dengan, Whistleblowing Organisasi, Iklim," Universitas Trisakti, 2020.

[6] E. Hariyani and A. A. Putra, "Pengaruh Komitmen Profesional, Lingkungan Etika, Intensitas Moral, Personal Cost Terhadap Intensi Untuk Melakukan Whistleblowing Internal (Studi Empiris Pada Opd Kabupaten Bengkalis)," J. Akuntansi, Keuang. dan Bisnis, vol. 11, no. 2, pp. 17-26, 2018.

[7] R. Bagustianto and Nurkholis, "Faktor-Faktor Yang Mempengaruhi Untuk Melakukan Tindakan Whistle-Blowing," Fak. Ekon. dan Bisnis Univ. Brawijaya, vol. 3, no. 1, pp. $1-18,2012$.

[8] G. L. \& X. Xiao, "Whistleblowing On Accounting-Related Misconduct: A Synthesis Of," J. Account. Lit., pp. 22-46, 2018.

[9] M. B. Curtis, "Are Audit-related Ethical Decisions Dependent upon Mood?," J. Bus. Ethics, vol. 68, pp. 191-2019, 2006.

[10] J. A. N. Aranya, J. Pollock, “An examination of professional commitment in public accounting," Account. Organ. Soc., vol. 5, pp. 271-280, 1981.

[11] I. Ajzen, The Theory of Planned Behaviour. Organizational Behaviour and Human 
Decision Processes, 50th ed. 1991.

[12] M. Bouville, "Whistle-Blowing and Morality," J. Bus. Ethics, vol. 81, pp. 579-585, 2008.

[13] M. W. Abdullah and H. Hasma, "Determinan Intensi Auditor Melakukan Tindakan Whistle-Blowing Dengan Perlindungan Hukum Sebagai Variabel Moderasi," EKUITAS (Jurnal Ekon. dan Keuangan), vol. 1, no. 3, pp. 385-407, 2018, doi: 10.24034/j25485024.y2017.v1.i3.2096.

[14] Q. Dempster, Whistleblower Para Pengungkap Fakta. Jakarta: Elsam, 2006.

[15] R. D. Winardi, "the Influence of Individual and Situational Factors on Lower-Level Civil Servants ' Whistle-Blowing Intention In Indonesia," Econ. Bus., vol. 28, no. 3, pp. 361-376, 2013.

[16] M. P. Near, J.P. dan Miceli, "Effective WhistleBlowing," Acad. Manag. Rev., vol. 20, pp. 679-708, 1995.

[17] D. M. dan S. D. Schultz Jr, Joseph J, Douglas A. Johnson, "An Investigation of The Reporting of Questionable Acts in an International Setting," J. Account. Res., vol. 31, pp. 75-103, 1993.

[18] S. Trisnaningsih, “ Pengaruh Komitmen terhadap Kepuasan Kerja Auditor: Motivasi sebagai Variabel Intervening (Studi Empiris pada Kantor Akuntan Publik di Jawa Timur ')," vol. 6 (2), pp. 199-216, 2003.

[19] A. Setiawati, Devi, Zilkaida, "perbedaan Komitmen Kerja Berdasarkan Orientasi Peran Gender Pada Karyawan Di Bidang Kerja Non Tradisional.," vol. 2, 2007.

[20] R. A. Hanif and O. dan Fajar, "Pengaruh Personal Cost Reporting, Status Wrong Doer dan Tingkat Keseriusan Kesalahan Terhadap Whistleblowing Intention," vol. 10, no. 1, pp. 11-20, 2017.

[21] G. dan C. N. Liyanarachchi, "The Impact of Moral Reasoning and Retaliation on Whistle-Blowing: New Zealand Evidence," J. Bus. Ethics, vol. 89, pp. 37-57, 2009.

[22] V. Djaja, "Pengaruh Persepsi Kontrol Perilaku Dan Personal Cost Terhadap Intensi Whistleblowing," Pros. Semin. Nas. Pakar Ke 3 Tahun 2020 Buku 2 Sos. Dan Hum., pp. 2.26.1-2.26.5, 2020.

[23] H. S. W. Arditya Dian Andika, Patricia Dhiana Paramita, "Pengaruh Personal Cost Dan Komitmen Whistleblowing Sebagai Variabel Moderasi," Maj. Inspiratif, vol. 6(12), pp. 88-100, 2021.

[24] R. Elias, “Auditing Student's Professional Commitment and Anticipatory Socialization and Their Relationship to Whistleblowing," Manag. Audit. J., vol. 23(3), pp. 283-294, 2008.

[25] L.-S. K. Hall, Matthew, Smith David, “"Accountants' Commitment to Their Profession: Multiple Dimensions of Professional Commitment and Opportunities for Future Research,”p. 89, 2008.

[26] S. E. dan S. M. Kaplan, "“An Examination of Auditors' Reporting Intentions When another Auditor is Offered Client Employment"," vol. 20 (1), pp. 45-63, 2001.

[27] R. 2010 Malik, " Analisis Perbedaan Komitmen Profesional dan Sosialisasi Antisipatif Mahasiswa PPA dan Non-PPA Pada Hubungannya Dengan Whistleblowing (Studi Kasus pada Mahasiswa Akuntansi Universitas Diponegoro)'.," Skripsi. Semarang Fak. Ekon. dan Bisnis, Univ. Diponegoro., 2010.

[28] B. R. Uma Sekaran, Research Methods for Business. 2014.

[29] Sugiyono, Metode Penelitian Kualitatif dan R\&D. Bandung: Alfabeta, 2009.

[30] W. Septianti, "Pengaruh Faktor Organisasional, Individual, Situasional dan Demografis terhadap Niat Melakukan Whistleblowing Internal," J. Simp. Nas. Akunt. XVI, 2013. 
[31] N. F. Ramadhany, "Personal Cost dan Efektivitas Whistleblowing System terhadap Pendeteksian Fraud dengan Self Efficacy sebagai (Studi pada KPP Pratama Makassar Selatan )," Skripsi, vol. FEB Islam, no. Akuntansi, p. UIN Alauddin, Makassar, 2017.

[32] R. Hall, ""Profesionalization and Bureaucratation".," no. New Jersey, pp. 92-104, 1968. 